\title{
Hydropus griseolazulinus, a striking new species from Paraíba, Brazil
}

\section{Pinheiro FGB ${ }^{1}$, Sá $\mathrm{MCA}^{2}$ and Wartchow $\mathrm{F}^{1 *}$}

\author{
${ }^{1}$ Universidade Federal da Paraíba, Departamento de Sistemática e Ecologia/CCEN, CEP 58051-970, João Pessoa, PB, \\ BRAZIL. \\ ${ }^{2}$ Universidade Federal do Rio Grande do Norte, Deptartamento de Botânica, Ecologia e Zoologia, Campus \\ Universitário, Lagoa Nova, CEP 59072-970, Natal, RN, BRAZIL.
}

Pinheiro FGB, Sá MCA, Wartchow F. 2013 - Hydropus griseolazulinus, a striking new species from Paraíba, Brazil. Mycosphere 4(2), 218-225, Doi 10.5943/mycosphere/4/2/4

A new species of Hydropus is described. This species is easy to identify due its greyish blue pileus with blue lamellae and yellow tinted edge, inamyloid basidiospores, scarcity of pleurocystidia and crowded cheilocystidia. A description, discussion, photographs and line drawings are provided.

Key words - Agaricomycetes - Agaricales - Neotropic - taxonomy

\section{Article Information}

Received 5 February 2013

Accepted 26 February 2013

Published online 17 March 2013

*Corresponding author: Felipe Wartchow - e-mail - fwartchow@yahoo.com.br

\section{Introduction}

Hydropus Kühner ex Singer was characterized to accommodate all omphalinoid, collybioid and mycenoid taxa with amyloid or inamyloid basidiospores and inflated pileocystidia on pileipellis (Singer 1982, 1986). Orton (1988) and Moncalvo et al. (2002), on the other hand, preferred to use the name Hydropus in the very narrow concept of Kühner (1938), i.e. amyloid basidiospores, lacking pleurocystidia and producing latex.

In Brazil, Hydropus is a relatively well inventoried genus. Singer (1953, 1973, 1982, 1989) reported more than 60 taxa, many of them as new species, mostly from Amazon. Later, Pegler (1997) cited 10 species from the state of São Paulo, including a new combination, Hydropus laetus (Corner) Pegler. From the state of Paraná, de Meijer (2001) numbered 23 taxa, but did not give them any names. Souza \& Aguiar (2004) cited two unnamed specimens of Hydropus from Amazon several years after Singer's (1982) monograph. The recent lists of de Meijer (2006, 2008, 2010) from Paraná reduced the number of taxa of Hydropus to 14 species. More recently, Drechsler-Santos et al. (2007) and Rosa \& Capelari (2009) cited some species in Atlantic Forest of Rio Grande do Sul and Minas Gerais, respectively. From Northeast Brazil, only six taxa are known: $H$. camarigibensis Singer, $H$. mesites Singer $H$. mycenoides (Dennis) Singer and $H$. semimarginellus Singer from Pernambuco, $H$. brunneoumbonatus (Dennis) Singer and $H$. phylogenus var. bahiensis Singer from the state of Bahia (Singer 1973, 1982).

Here we describe a new and striking species of Hydropus from the 'restinga' forest from the State of Paraíba, Brazil. 
Mycosphere Doi 10.5943/mycosphere/4/2/4
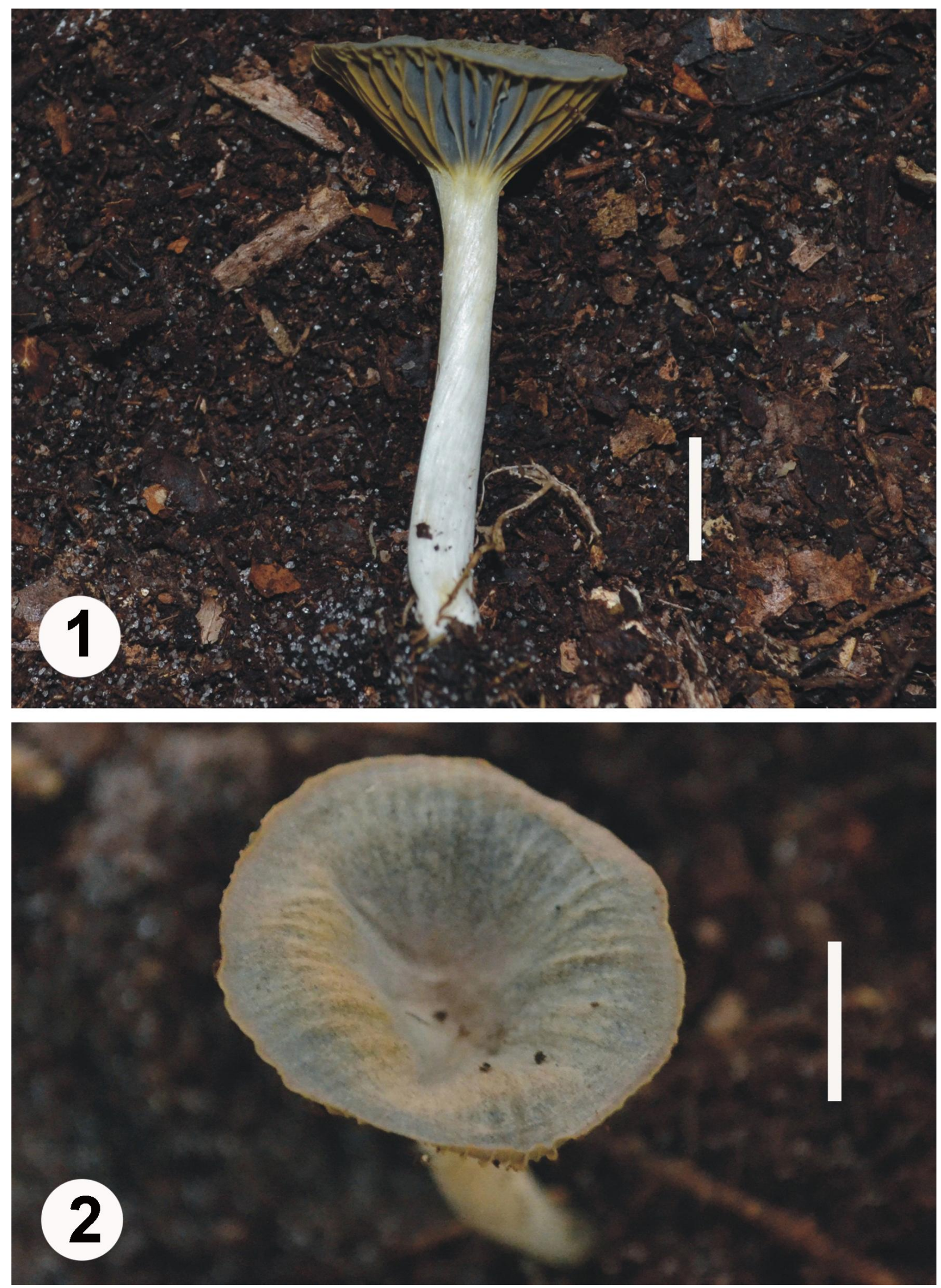

Figs 1-2 - Hydropus griseolazulinus (holotype). 1 Basidiome in side-view. 2 Pileus surface. Bars = $10 \mathrm{~mm}$. 


\section{Methods}

The new species was collected at the "Floresta Nacional da Restinga de Cabedelo", an Atlantic Forest protected area comprising about 100 ha, located in municipality of Cabedelo, State of Paraíba, Brazil. The area comprises a 'restinga' forest, with 160 species of angiosperms belonging to 61 families, of which the most diverse are Myrtaceae, Leguminosae (all subfamilies), Rubiaceae, Poaceae and Euphorbiaceae (Pontes \& Barbosa 2008). Microscopic observations were made from material mounted in $3 \% \mathrm{KOH}$, Congo red solution and Melzer's reagent. Color codes are ' $\mathrm{K}$ ' (Kelly 1965) and 'OAC' (Online Auction Color 2004). Presentation of basidiospore data follows the methodology proposed by Tulloss et al. (1992), slightly modified by Wartchow (2012) and Wartchow et al. (2012). Measurements and statistics are based on 30 spores. Abbreviations include $\mathbf{L}(\mathbf{W})=$ average basidiospore length (width), $\mathbf{Q}$ $=$ the length $:$ width ratio range as determined from all measured basidiospores, and $\mathbf{Q m}=$ the $Q$ value averaged from all basidiospores measured. The holotype is deposited at JPB (Thiers 2012).

\section{Results}

Hydropus griseolazulins F.G.B. Pinheiro, Sá \& Wartchow, sp. nov.

MycoBank 802943

Holotype- BRAZIL. PARAÍBA. Cabedelo, Floresta Nacional da Restinga de Cabedelo, 01.vi.2012, F.G.B. Pinheiro \& F. Wartchow FW 29/2012 (JPB 51899).

Etymology - from Latin 'griseo' (=grey) and lazulinus (=blue), regarding to greyish blue pileus.

Basidiome small, solitary. Pileus 25 $\mathrm{mm}$ in diam., subinfudibuliform, greyish blue (OAC 283-284; K 190 I. b Gray) with yellowish tints; surface velvety overall; margin smooth, not sulcate, straight; context greyish blue, thin about $1 \mathrm{~mm}$ thick near centre. Lamellae decurrent with short tooth, spaced, thick, dark blue (OAC 280-281; K 182. M Blue); edge entire, buff-sulfur-yellow (OAC 825; K 85. deep Y); lamellulae common, attenuating. Stipe $42 \times 4 \mathrm{~mm}$, slightly tapering towards base, whitish; surface with shallowly twisted grooves, from near base to apex; smooth at base, glabrous in all length; context hollow; rhizomorphs present. Odour indistinct.

Basidiospores (7.4-)7.7-9.4 × (4.1)4.3-5.6(-5.9) $\mu \mathrm{m},(\mathbf{L}=8.4 \mu \mathrm{m} ; \mathbf{W}=5.1 \mu \mathrm{m}$; $\mathrm{Q}=1.50-1.90 ; \mathbf{Q m}=1.70)$, inamyloid, hyaline, colourless, subglobose to broadly ellipsoid sometimes globose, smooth, thin walled; apiculus sublateral; content as a large guttule. Basidia (33-)43-49 × 6.5-8.7 $\mu \mathrm{m}$, clavate, 4-esterigmate about $10 \mu \mathrm{m}$ high, clamp connections absent. Pleurocystidia very rare, (21-)31-41 × (5-)6-10 $\mu \mathrm{m}$, lageniform, colourless, thin walled. Lamella edge sterile, with crowded cheilocystidia. Cheilocystidia $28-36 \times 7-10 \mu \mathrm{m}$, clavate to slender clavate to sometimes slender ventricose, hyaline, thin walled. Lamella trama regular to subregular, sarcodimitic, made by two types of hyphae, one wider 14-21 $\mu \mathrm{m}$, sometimes long and thick walled up to $1 \mu \mathrm{m}$ thick, and other $3-5 \mu \mathrm{m}$ wide. Stipe context with hyphae $2.5-11 \mu \mathrm{m}$ in diam., abundant, colourless, longitudinally oriented. Pileus context sarcodimitic; made of hyphae to $13.5 \mu \mathrm{m}$ in diam., mostly with thick walled up to $1-1.8 \mu \mathrm{m}$ thick. Stipitipellis with abundant caulocystidia dispersed along the stipe, (15-)21-31 × 6.7-9.5 $\mu \mathrm{m}$, broadly clavate to clavate, hyaline, thin walled. Pileipellis a disrupting hymenioderm with pileocystidia, 44-75 × 15-26 $\mu \mathrm{m}$, broadly clavate, clavate occasionally fusoid, pale colourless to almost hyaline, thick walled to $0.8 \mu \mathrm{m}$ thick.

Known distribution - only known from the type locality.

Habit - solitary on sandy soil in 'restinga' vegetation Atlantic Forest.

\section{Taxonomic observation on Hydropus}

Recent phylogenetic analysis (Moncalvo et al. 2002, Matheny et al. 2006) put in check the systematic of Hydropus s.l. According to them Hydropus s.str. must be restricted to Kühner's original concept. However, they only used $H$. sect. Hydropus sensu Singer (1982), not taxa of $H$. sect. Mycenoides Singer. They observed that $H$. scabripes (Murrill) Singer, belonging to sect. Floccipedes (Kühner) Singer ex Singer (1961), did not cluster with taxa of Hydropus s.str. According to Singer (1982) diagnostic 


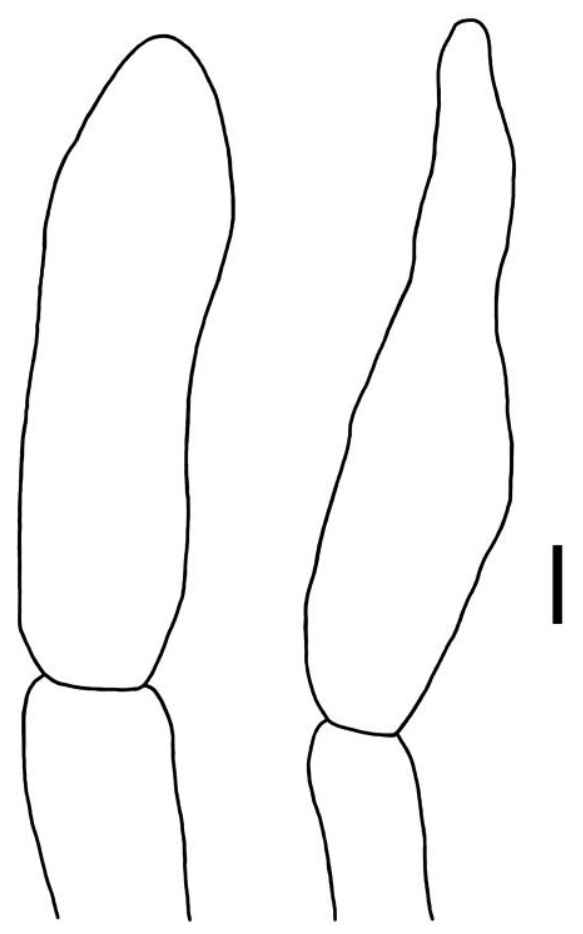

3

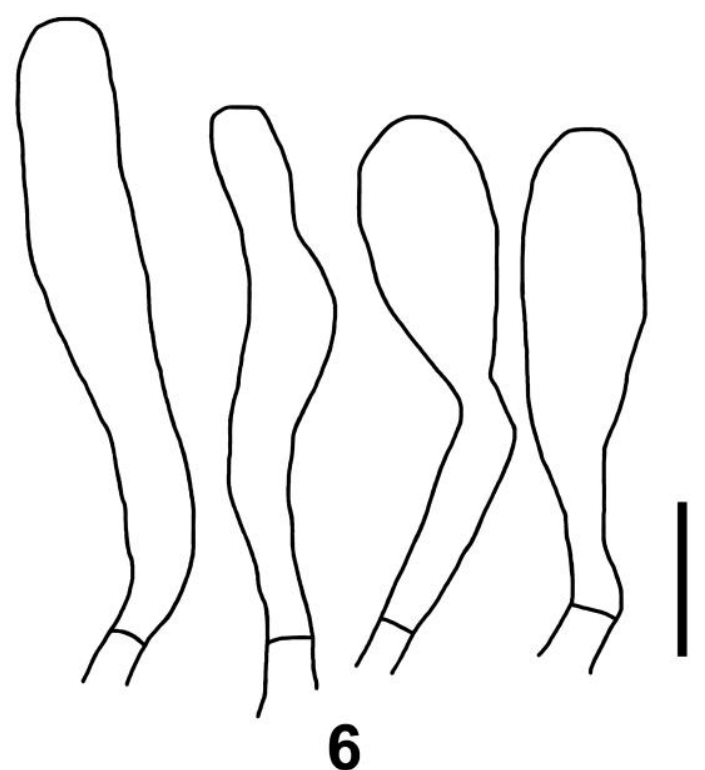

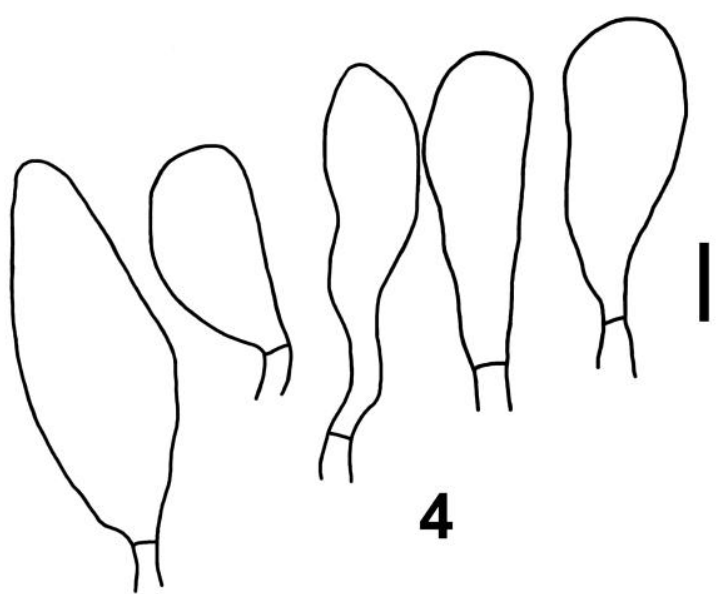
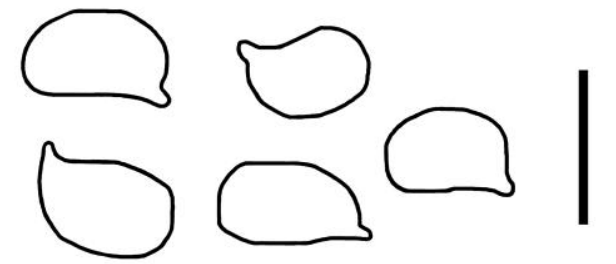

5
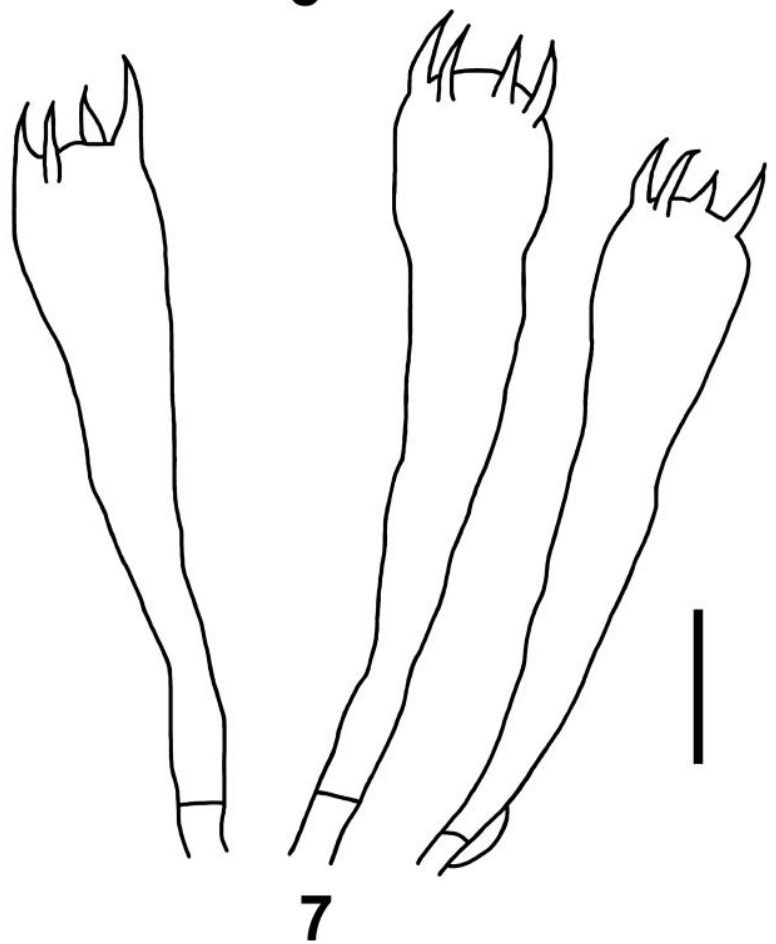

Figs 3-7 - Hydropus griseolazulinus (holotype). 3 Pleurocystidia. 4 Pileocystidia. 5 Basidiospores. 6 Cheilocystidia 7 Basidia. Bars $=10 \mu \mathrm{m}$.

features to segregate Hydropus s.str. and $H$. scabripes (and possibility other member of sect. Floccipedes) are lack of, or scanty pileocystidia and the presence of cutis in the second group. Since material of $H$. sect. Mycenoides used in phylogenetic analysis by
Moncalvo et al. (2002) and Matheny et al. (2006) is lacking, we prefer to use the generic name Hydropus for our new species, since it agrees with some feature (i.e., pileipellis structure) with $H$. sect. Hydropus sensu Singer (1982). 


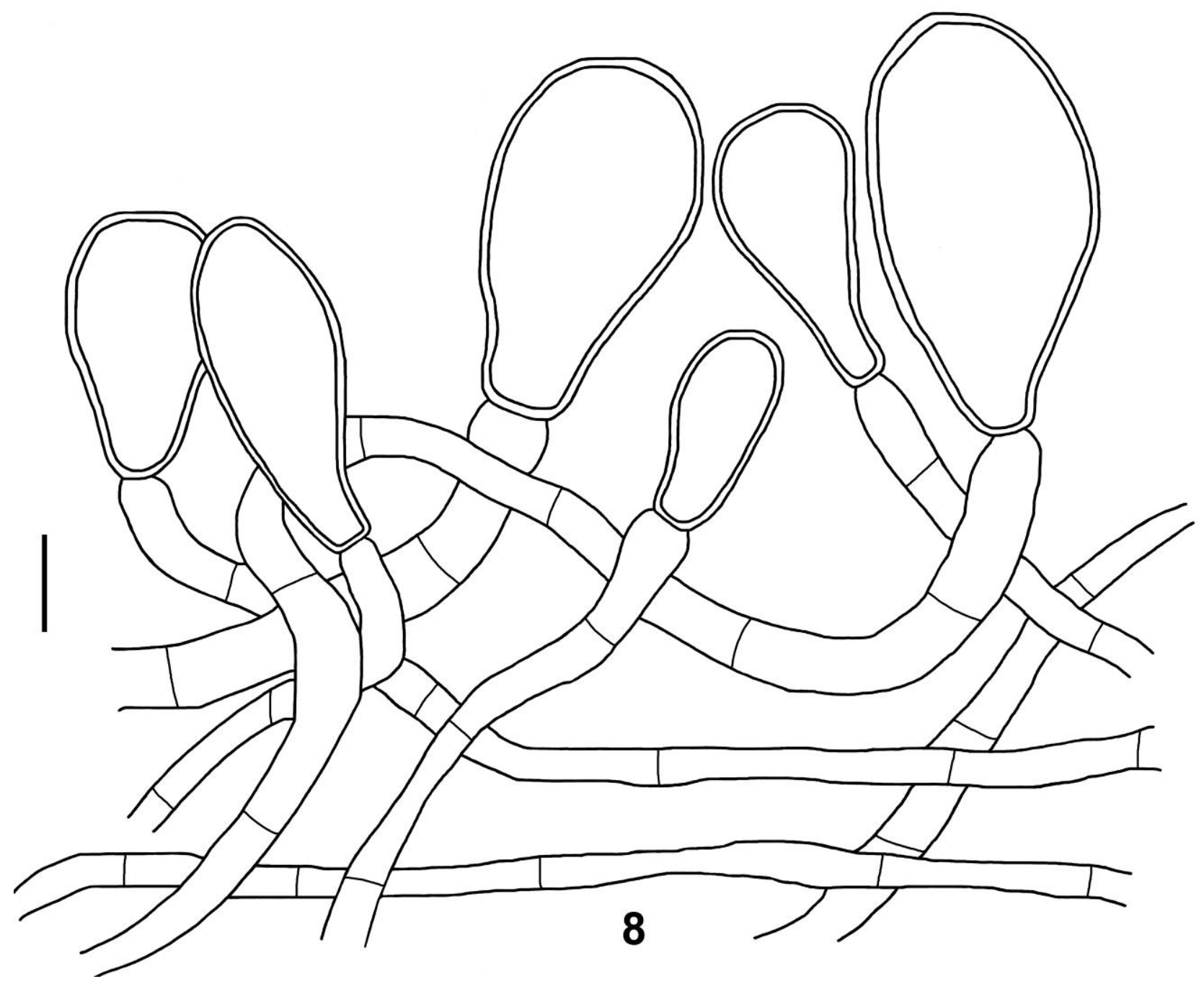

Fig. 8 - Hydropus griseolazulinus (holotype). Details of the pileipellis showing the thick walled pileocystidia. Bar $=10 \mu \mathrm{m}$.

\section{Discussion}

The omphalinoid habit and a pileipellis a disrupting hymeniform with broadly clavate pileocystidia are typical feature of the genus Hydropus (Singer 1982, 1986). Hydropus griseolazulinus can be keyed in $H$. sect. Mycenoides subsect. Anthidepas Singer due the presence of pileocystidia forming a disrupting hymeniform layer in the pileipellis, inamyloid basidiospores and presence of thin-walled cystidia (Singer 1982). Among this subsection, the scarcity of pleurocystidia, the yellow tints in the lamellae and somewhat greyish tints in the pileus, our new species can be compared with $H$. terraefirmae Singer. In spite of the slightly similar basidiospores size, $6.5-8.5 \times$ $4.2-5.5 \mu \mathrm{m}$, it differs from our new species in the presence of ventricose cheilocystidia, and lack of any bluish colour in the basidiome (Singer 1982).
'Trogia subviride Corner', although reported with bluish tints and somewhat similar basidiospores size $(7-10 \times 4-5 \mu \mathrm{m})$, differs in the greyish tinged greenish ochraceous to greenish blue pileus color, subdistant to rather crowded and whitish lamellae, white then yellowish in age stipe, abundant pleurocystidia and larger cheilocystidia, and growing on dead wood (Corner 1966, 1991).

Corner (1966, 1991) emphasized the importance of the sarcodimitic tissue as taxonomic characters, and considered the genus Trogia Fr. in a very wide sense, dividing this genus in four groups. One of these groups is keyed as possessing cheilocystidia forming a sterile lamellae edge. Some of them have pileipellis structure similar to Hydropus sensu Singer (1982); T. pleurotoides Corner has a pleurotoid habit, and T. calyculus Corner 
differs primarily in the greenish rather than bluish color in the pileus.

Trogia cyanea Corner, compared by Singer (1982) with $H$. terraefirmae, had the holotype recently revised by Kumar \& Manimohan (2009: 431). However, several features, i.e. easily reviving basidiomes, discoid stipe base with radiating basal mycelium, narrow, forked lamellae and the pileipellis as a cutis, are diagnostic features for maintaining this name in Trogia rather than Hydropus.

Another interesting feature of our new species is the occurrence of long, thick-walled hyphae in the lamella trama and pileus context. This sarcodimitic tissue (differently as proposed by Corner 1966, 1991, who considered it as one diagnostic feature for Trogia) is widespread among several taxa of Agaricales. Redhead (1987) reported several taxa that present this specialized tissue, including two Hydropus analysed by him, $H$. kauffmanii (A.H. Sm.) Singer and $H$. marginellus Pers.: Fr.) Singer. Singer (1986) also pointed out this character in Hydropus.

Singer (1961), Singer \& Grinling (1967), Dennis (1968), Pegler \& Rayner (1969), Machol \& Singer (1977), Bas (1983), Maas Geesteranus \& Hausknecht (1993), Clémençon \& Hongo (1994), Hausknecht et al. (1997), Pegler (1997), Pérez-de-Gregório (2001), Moreau \& Cortecuisse (2004), Seok et al. (2005), de Meijer (2008) and Holec (2008) described many species of Hydropus from several parts of the world, viz. Africa, Asia, Europe, North and South America, and Caribbean. None of them are reported with blue tints. As far as we know, we present a novel macroscopic feature that seems unique among the genus.

\section{Acknowledgements}

The authors wish to thank Dr. Clark L. Ovrebo for providing a pre-submission review of the manuscript, and Dr. M. Regina Vasconcellos Barbosa, Dr T.K. Arun Kumar and Dr P. Manimohan for sending important literature. CNPq (APV Proc. 451590/2012-0) is acknowledged for financial support, the ICMBio (SISBIO Proc. 32969-4) for authorized collection trips to FLONA Restinga de Cabedelo and PPBio Semi-Árido
(CNPq/MCT Proc. 60/2009) for help in financial support and acquisition of equipment for study. Also thanks to Dr. Maria Regina Barbosa and TAXON laboratory for the use of study and facilities.

\section{References}

Bas C. 1983 - A new European species of Hydropus, H. moserianus, n. spec. Sydowia 36, 6-10.

Clémençon H, Hongo T. 1994 - Notes on three Japanese Agaricales. Mycoscience 35, 21-27.

Corner EJH. 1966 - A monograph of cantharelloid fungi. Oxford University Press, London.

Corner EJH. 1991 - Trogia (Basidiomycetes). The Garden Bulletin, Singapore Supplement 2, 1-100.

Dennis RWG. 1968 - Some Agaricales from the Blue Mountains of Jamaica. Kew Bulletin 22, 73-85.

Drechsler-Santos ER, Pastorini LH, Putzke J. 2007 - Primeiro relato de fungos Agaricales em fragmento de mata nativa em Frederico Westphalen - RS. Revista Brasileira de Biociências 5 (suplemento 2), 471-473.

Hausknecht A, Krisai-Greilhuber I, Koflac W. 1997 - Die Gattung Hydropus in Österreich. Österreichische Zeitschrift für Pilzkunde 6, 181-210.

Holec J. 2008 - Ecology of the rare fungus Hydropus atramentosus (Basidiomycota, Agaricales) in the Czech Republic and its potential value as bioindicator of oldgrowth forests. Czech Mycology 60, 125-136.

Kelly KL. 1965 - Color name charts illustrated with centroid colors. Standard Sample No. 2106. Supplement to National Bureau of Standards Circular No. 553. U.S. Government Printing Office, Washington.

Kühner R. 1938 - Le Genre Mycena. Encyclopédie Mycologique 10, 1-710.

Kumar TKA, Manimohan P. 2009 Rediscovery of Trogia cyanea and a record of $T$. infudibuliformis (Marasmiaceae, Agaricales) from Kerala State, India. Mycotaxon 109, 429-436. 
Maas Geesteranus RA, Hausknecht A. 1993 Hydropus nitens, a new species from Austria. Österreichische Zeitschrift für Pilzkunde 2, 15-18.

Machol RE, Singer R. 1977 - Taxonomic position of Hydropus floccipes and allied species-a quantitative approach. Mycologia 69, 1162-1172.

Matheny PB, Curtis JM, Hofstteter V, Aime MC, Moncalvo J-M, Ge Z-W, Yang Z-L, Slot JC, Ammiratti JF, Baroni TJ, Bougher NL, Hughes KW,Lodge DJ, Kerrigan RW, Seidl MT, Aanen DK, DeNitis M, Daniele GM, Desjardin DE, Kropp BR, Norvell LL, Parker A, Vellinga, Vilgalys R, Hibbett DS - 2006. Major clades of Agaricales: a multilocus phylogenetic overview. Mycologia 98, 982-995.

de Meijer AAR. 2001 - Mycological work in the Brazilian state of Paraná. Nova Hedwigia 72, 105-159.

de Meijer AAR. 2006 - Preliminary list of the macromycetes from the Brazilian state of Paraná. Boletim do Museu Botânico Municipal (Curitiba) 68, 1-55.

de Meijer AAR. 2008 - Notable macrofungi from Brazil's Paraná pine forests/Macrofungos notáveis das florestas de peinheiro-do-paraná. Embrapa Florestas, Colombo.

de Meijer AAR. 2010 - Preliminary list of the macromycetes from the Brazilian state of Paraná: corrections and updating. Boletim do Museu Botânico Municipal (Curitiba) 72, 1-9.

Moncalvo J-M, Vilgalys R, Redhead AS, Jonhson JE, James TY, Aime MC, Hofstetter V, Verduin SJW, Larsson E, Baroni TJ, Thorn RG, Jacobsson $\mathrm{S}$, Clémençon H, Miller Jr. OK. 2002 - One hundred and seventeen clades of euagarics. Molecular Phylogenetics and Evolution 23, 357-400.

Moreau P-A, Cortecuisse R. 2004 - Hydropus kauffmanii, first records from Europe. Mycotaxon 89, 331-339.

Online Auction Color. 2004 - The Online Auction Color Chart. Online Auction Color Co., Stanford.

Orton PD. 1988 - Notes on British Agarics. IX. Transactions of the British Mycological
Society 91, 545-571.

Pegler DN. 1997 - The agarics of São Paulo, Brazil. Royal Botanic Garden, Kew.

Pegler DN, Rayner RW. 1969 - A contribution to the Agaric Flora of Kenya. Kew Bulletin 23, 247-412.

Pérez-de-Gregório MÀ. 2001 - Hydropus floccipes (Fr.) Singer f. luteipes (A. Ortega et Zea) stat. nov., a Catalunya. Revista Catalana de Micologia 23, 9193.

Pontes AF, Barbosa MRV. 2008 - Floristic Survey of the AMEM Forest, Cabedelo, Paraíba, Brazil. Memoirs of the New York Botanical Garden 100, 458-473.

Redhead SA. 1987 - The Xerulaceae (Basidiomycetes), a family with sarcodimitic tissues. Canadian Journal of Botany 65, 1551-1562.

Rosa LH, Capelari M. 2009 - Agaricales from Atlantic rain forest fragments in Minas Gerais, Brazil. Brazilian Journal of Microbiology 40, 846-851.

Seok S-J, Kim Y-S, Yoo K-H, Kim, J-H. 2005. Taxonomic study on some unrecorded species of Korean Hydropus. Mycobiology 33, 182-187.

Singer R. 1953 - Type studies on Basidiomycetes. Lilloa 26, 57-159.

Singer R. 1961 - Diagnoses Fungorum novorum Agaricalium II. Sydowia 15, 45-83.

Singer R. 1973 - Diagnoses Fungorum Novorum Agaricalium. III. Beihefte zur Sydowia 7, 1-106.

Singer R. 1982 - Hydropus (BasidiomycetesTricholomataceae-Mycenae). Flora Neotropica Monograph 32. The New York Botanical Garden, New York.

Singer R. 1986 - The Agaricales in Modern Taxonomy. Koeltz Scientific Books, Koegnistein.

Singer R. 1989 - New taxa and new combinations of Agaricales (Diagnoses Fungorum Novorum Agaricalium IV). Fieldiana, Botany 21, 1-133.

Singer R, Grinling K. 1967 - Some Agaricales from the Congo. Persoonia 4, 355-377.

Souza HQ, Aguiar IJA. 2004 - Diversidade de Agaricales (Basidiomycota) na Reserva Biológica Walter Egler, Amazonas, Brasil. Acta Amazonica 34, 43-51. 
Mycosphere Doi 10.5943/mycosphere/4/2/4

Thiers B. 2012 [continuously updated] - Index Herbariorum: A global directory of public herbaria and associated staff. New York Botanical Garden's Virtual Herbarium.

<http://sweetgum.nybg.org/ih/> accessed 05 November 2012.

Tulloss RE, Ovrebo CL, Halling RE. 1992 Studies on Amanita (Amanitaceae) from Andean Colombia. Memoirs of the New York Botanical Garden 66, 1-46.
Wartchow F. 2012 - Clavulina incrustata, a new species from Pernambuco, Brazil. Cryptogamie, Mycologie 33, 105-113.

Wartchow F, Buyck B, Maia LC. 2012 Cantharellus aurantioconspicuus (Cantharellales), a new species from Pernambuco, Brazil. Nova Hedwigia 94, 129-137. 